\title{
The effect of hydrated oatmeal on quality of the symbiotic fer- mented milk product
}

\author{
Irina V. Sukhova, Tatyana N. Romanova*, Lidia A. Korosteleva, Rinat H. Baimishev, and Elena V. Dolgosheva
}

Samara State Agrarian University, Kinel 446442, Samara region, Russia

\begin{abstract}
In recent years, there has been a trend to develop and produce special products. Improving food technology through the use of hydrated oatmeal makes it possible to enrich fermented milk products with proteins, dietary fiber, trace elements and vitamins. Oat flakes were used as a nutrient medium for microorganisms in a fermented milk product. Lactobacilli and acidophilus bacillus produce organic acids which leads to the inhibition of the vital activity of pathogenic microorganisms. The use of hydrated oat flakes in an amount of $6 \%$ at the stage of fermentization at a temperature of $420^{\circ} \mathrm{C}$ has a positive effect on quality of the fermented milk product (yogurt) and development of lactic acid bacteria.
\end{abstract}

\section{Introduction}

Dairy products have valuable dietary and therapeutic properties. They contain all the constituent elements of milk in a more digestible form. The high digestibility of milk drinks is a consequence of their effect on secretory and evacuation activities of the stomach and intestines, as a result of which the glands of the digestive tract secrete enzymes that accelerate the digestion of food [1].

Functional products (probiotics and prebiotics) are widely used in Russia. At the moment, in the modern world, prebiotics are given special attention (yogurts, sour-milk products, baby food, various cereals). Dietary fiber is a food component that is not digested by the digestive enzymes of the human body, but processed by the beneficial intestinal microflora. Dietary fiber is an essential component of nutrition. Human nutrition should be balanced [2, 3].

The content of oatmeal in fermented milk products makes the product prebiotic. Replenishing the body with a sufficient number of prebiotics is not so difficult; the main thing is to prevent consequences of a lack of vitamins. Therefore, the production of dairy products with oatmeal will provide the population with a full-fledged dietary and healthy product [4].

It is necessary to create new food products, which, unlike the traditional ones, are intended for the purpose through the use of functional ingredients.

Food additives based on plant materials are wellknown. The disadvantages of such additives are their volume limitations, low functional and biological properties, limited domestic production resources and low organoleptic properties of the finished product. It is necessary to improve biological and functional properties of the product, reduce the cost of production by removing imported and using non-expensive sources of domestic production.

The creation of industrial technologies for the production of concentrated protein products from plant materials is one of the main directions of increasing food resources, improving nutritional quality and increasing the nutritional and biological value of food products.

Under the deficiency of nutritious food protein, one of the main areas of food biotechnology is the search for alternative sources of protein among resources of plant, microbiological, and fungal origin [5].

The use of food protein supplements for the production and enrichment of food is an important issue of great economic importance. Application of plant products improves organoleptic and physical and chemical indicators $[6,7]$.

\section{The purpose of this research}

The research was aimed at 1) determining quality of oatmeal used in the production of symbiotic sour-milk product; 2) determining the optimal product impact on the dosage of hydrated oatmeal (yogurt); 3) improving the technology for the production of fermented milk product using hydrated oatmeal. The research object is a fermented milk symbiotic product (yogurt) with hydrated oatmeal. The subject is hydrated oat flakes and their influence on quality management of a symbiotic sourmilk product.

\section{Materials and methods}

A symbiotic was introduced into the fermented milk product as a functional ingredient. Acidophilic sourdough had the form of a powdery or crystalline mass, of light beige or cream color. The symbiotic includes Lac-

Corresponding author: roma_alisa_ru@mail.ru 
tobacillusacidophilus microorganisms with a content of lactic acid bacterial organisms of at least $10 \mathrm{CFU} / \mathrm{g}$.

Thermophilic streptococcus was used as the main starter culture, and acidophilus bacillus was used as a probiotic culture.

Since we used an acidophilus bacillus, and oatmeal as a prebiotic medium, the product is synbiotic.

The acidophilus bacillus is one of the varieties of lactic acid bacteria. These are useful microorganisms that contribute to the digestion of proteins and slow down the growth of pathogenic microorganisms due to the formation of lactic acid, hydrogen peroxide, enzymes, B vitamins and anti-bacterial substances.

Thermophilic streptococcus (Streptococcusthermophilus) protects the body from harmful bacteria, ensures the normal functioning of the immune system, promotes digestion and helps the absorption of nutrients. Ferment is a lyophilized biomass of lactic acid microorganisms of the species Streptococcusthermophilus.

The combination of milk and vegetable proteins is a more perfect composition in terms of amino acid composition compared to milk protein; therefore, when conducting research, a nutritional supplement in the form of hydrated oatmeal was introduced into the composition of yogurt. Oatmeal contains a large amount of dietary fiber, which positively affects the metabolism and is required for the normal functioning of the human body. The daily need for insoluble forms of dietary fiber is $30-50 \mathrm{~g} /$ day for an adult. In Russia, the consumption of dietary fiber is less than a third of the daily norm.

Dietary fibers are food components that are not digested by the digestive enzymes, but are processed by the beneficial intestinal microflora. Dietary fiber is an essential component of nutrition.

At the initial stage of production of a symbiotic sourmilk product (yogurt), microbiological impurities are cleaned by bactofugs, whose principle is similar to separators; milk is normalized by the content of fat and protein only after milk is purified. Cooling and storage cannot be carried out at low volumes. These operations must be carried out immediately after cleaning. Milk is a good medium for lactic acid, butyric acid, propionic acid and putrefactive bacteria. The growth and development of lactic acid bacteria stops at $100^{\circ} \mathrm{C}$ and ceases at $2-4{ }^{\circ} \mathrm{C}$. Thus, the cooling temperature is the main parameter that determines the bacterial contamination and acidity of milk. Therefore, the cooling temperature of milk should not exceed $6{ }^{\circ} \mathrm{C}$. Milk should be kept for no more than 20 hours at $10^{\circ} \mathrm{C}$, further storage changes its composition.

Heating and separation are carried out to normalize milk. Milk must be heated to 40-45 0C and separated. The separation process is a mechanical separation of milk into fractions under the influence of the centrifugal force. Separation is used to separate milk into cream and skim milk, as well as to clean it from mechanical and natural impurities. When separating, cream is obtained with a mass fraction of fat of $32-37 \%$.

The pasteurization mode is selected depending on the bacterial contamination of milk and properties of the clot obtained by coagulation of milk. Homogenization provides a homogeneous composition of the finished product without sludge fat. The consistency of the product is more viscous. During storage, the clot remains uniform and serum is not secreted. The normalized milk mixture should enter the homogenizer. At a pressure of $12.5 \pm$ $2.5 \mathrm{MPa}$ and at a temperature of at least $60^{\circ} \mathrm{C}$, the globules break up the fat globules, and milk fat that is destabilized as a result of mechanical and thermal effects acquires a protein-lecithin shell. The size of fat globules during homogenization is reduced by 10 times.

The mixture was pasteurized at a temperature of (92 \pm 2 ) ${ }^{\circ} \mathrm{C}$ with a holding time of 20 minutes. A starter culture was prepared in accordance with the "Technological Instructions for the Preparation and Use of Ferment and Ferment Concentrates for Fermented Milk Products at Dairy Enterprises".

To revitalize the starter culture of direct thermophilic streptococcus (DTS), sterile milk was used. At an activation temperature of $42^{\circ} \mathrm{C}$, the required amount of thermophilic streptococcus starter was added. Activation lasts for 30 minutes. The introduction of oatmeal was carried out according to the recipe in the amount of $6 \%$. For this, the flakes had to be evaluated for quality. Then the flakes were introduced into warm (40-45C) milk (hydrated) and introduced into the product. Ready bioyogurt is stored at a temperature of $(4 \pm 2){ }^{\circ} \mathrm{C}$ for no more than 7 days.

At the beginning of the studies, the fermented milk probiotic product produced without food additives was taken as a control variant; hydrated oat flakes were introduced into other experimental variants at various stages of the technological process.

All dairy products must be produced in accordance with the requirements of these standards in compliance with sanitary norms and rules.

At the first stage, the assessment of the quality of milk was carried out.

Milk was evaluated by organoleptic quality (consistency, taste, smell and color) and physicochemical (fat content, titratable acidity, density, SOMO, somatic cells) indicators. Milk was pasteurized at a temperature of $92^{\circ}$ $\mathrm{C}$ with a holding time of 30 minutes. Then, it was cooled to $42{ }^{\circ} \mathrm{C}$, and a protosymbiotic starter culture was introduced and cooled to $10{ }^{\circ} \mathrm{C}$. At various stages of production and at different temperatures of processing the milk mixture and the finished product, oatmeal was added. Before producing flakes, they were checked for quality (color, smell, taste, mineral content) and weighed according to the recipe.

Five experimental variants were developed, oat flakes were introduced hydrated in the amount of $6 \%$ in each experimental variant at various stages of production.

The experimental scheme for studying the effect of the stages of hydrated oat flakes on the quality of the synbiotic fermented milk product is presented in Figure 1. 


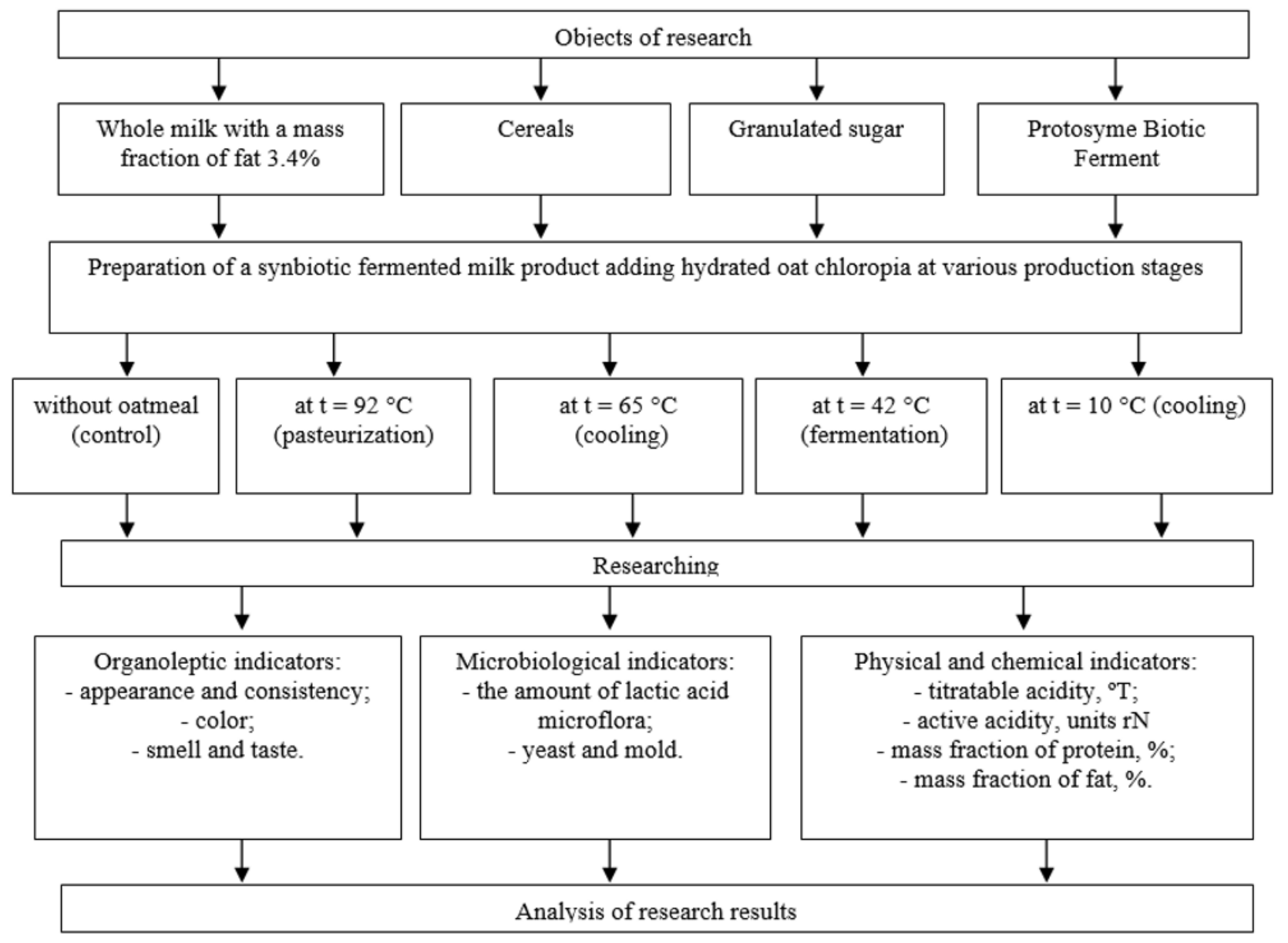

Fig. 1. Scheme of the study of the effect of adding hydrated oatmeal on quality of a synbiotic dairy product

The scheme for studying the influence of the stages of adding oatmeal on the quality of a sour-milk product presents a sequence of studies to determine the quality of the components that make up a sour-milk product by organoleptic, physico-chemical and microbiological indicators. In addition, a technology for the production of a functional product by modeling the process of product manufacturing was developed.

Oatmeal contains a lot of coarse dietary fiber that is not digested. Therefore, a synbiotic sour-milk product with oatmeal can be considered a prebiotic product. According to the classification of the Technical Regulations of the Customs Union and GOST 33491-2015 "Sourmilk products enriched with bifidobacteria, bifidum. Technical conditions", we developed a synbiotic sourmilk product with oatmeal in the conditions of bioyogurt production.

The recipe for a synbiotic sour-milk product produced using oatmeal is presented in Table 1 .

Table 1. Recipes for a synbiotic sour-milk product per $1000 \mathrm{~kg}$, kg

\begin{tabular}{|l|c|c|c|c|c|}
\hline \multirow{2}{*}{$\begin{array}{c}\text { Raw materials, } \\
\text { kg }\end{array}$} & \multicolumn{5}{|c|}{$\begin{array}{c}\text { Experimental options: preparation of a synbiotic sour-milk product with oat flakes at various } \\
\text { stages of production }\end{array}$} \\
\cline { 2 - 6 } & $\begin{array}{c}\text { without } \\
\text { oatmeal } \\
\text { (control) }\end{array}$ & $\begin{array}{c}\text { Addition of oat- } \\
\text { meal into the } \\
\text { mixture at } 92^{\circ} \mathrm{C}\end{array}$ & $\begin{array}{c}\text { addition of oat- } \\
\text { meal into the } \\
\text { mixture during } \\
\text { cooling at } 65^{\circ} \mathrm{C}\end{array}$ & $\begin{array}{c}\text { addition of oatmeal } \\
\text { into the mixture } \\
\text { during the fermen- } \\
\text { tation at } 42^{\circ} \mathrm{C}\end{array}$ & $\begin{array}{c}\text { addition of oatmeal } \\
\text { into the finished } \\
\text { product at } 10^{\circ} \mathrm{C}\end{array}$ \\
\hline $\begin{array}{l}\text { Whole milk with } \\
\text { a mass fraction of } \\
\text { fat 3.4\% }\end{array}$ & 949.95 & 889.95 & 889.95 & 889.95 & 889.95 \\
\hline $\begin{array}{l}\text { Protosymbiotic } \\
\text { Ferment }\end{array}$ & 0.05 & 0.05 & 0.05 & 0.05 & 0.05 \\
\hline Sugar & 50 & 50 & 50 & 50 & 50 \\
\hline Oat bran & - & 60 & 60 & 1000 & 60 \\
\hline Product yield & 1000 & 1000 & 1000 & & 1000 \\
\hline
\end{tabular}


Table 1 presents the formulations for all experimental variants of synbiotic sour-milk products prepared with oatmeal in the amount of $6 \%$ at various stages of production without taking into account losses.

Experimental variants: pasteurization temperature is $92^{\circ} \mathrm{C}$, cooling temperature of the milk mixture is $65^{\circ} \mathrm{C}$, fermentation temperature of the milk mixture is $42^{\circ} \mathrm{C}$, cooling temperature of the finished product is $10^{\circ} \mathrm{C}$.

All raw materials and auxiliary materials must be safe for humans and meet the hygienic requirements for safety and nutritional value of food products in accordance with the Technical Regulation of the Customs Union "On the Safety of Milk and Dairy Products" (TR TS 033-2013).

The appearance and color of raw milk was determined visually in accordance with the standards. The taste was assessed selectively, after heating the sample $\left(20 \mathrm{~cm}^{3}\right.$ of milk was heated to $35^{\circ} \mathrm{C}$ ).

The organoleptic properties of oat flakes were determined by color, smell, and taste. Organoleptic quality indicators of appearance, consistency, color, smell and taste were determined on the finished symbiotic product. Titratable acidity, ${ }^{\circ} \mathrm{T}$, active acidity, $\mathrm{pH}$, units, protein mass fraction, $\%$ and fat mass fraction, $\%$ were determined.

\section{Research results}

The main criterion that affects the organoleptic characteristics of a synbiotic sour-milk product is quality of milk and quality of the introduced components.

Considering the fact that milk cannot be improved during processing, and can be stabilized, any scheme related to the quality of milk should begin with the process of production and primary processing of milk. Therefore, quality of raw milk and secondary raw materials is fundamental for the production of high-quality dairy products.

Laboratory studies were conducted on raw milk. The milk mixture had the following organoleptic characteristics according to GOST 31449-2013 Natural raw milk (Table 2).

The results of the assessment of milk quality by physico-chemical indicators are shown in Table 3.

Table 2. Organoleptic indicators of milk quality

\begin{tabular}{|l|c|}
\hline \multicolumn{1}{|c|}{ Indicator } & Indicator values \\
\hline Taste and smell & Clean, pleasant, slightly sweet \\
\hline Color & White \\
\hline Consistency and appearance & Homogeneous liquid, without sediment \\
\hline
\end{tabular}

Table 3. Physico-chemical indicators of milk quality

\begin{tabular}{|l|c|}
\hline \multicolumn{1}{|c|}{ Indicator } & Indicator values \\
\hline Mass fraction of fat, \% & 3.4 \\
\hline Mass fraction of protein, $\%$ & 3.3 \\
\hline Sourness, ${ }^{\circ} \mathrm{T}$ & 18 \\
\hline Milk temperature, ${ }^{\circ} \mathrm{C}$ & 6 \\
\hline COMO, $\%$ & 9.11 \\
\hline Density, ${ }^{\circ} \mathrm{A}$ & 28.7 \\
\hline Somatic cells, thousand cells & 187 \\
\hline
\end{tabular}

According to the organoleptic and physico-chemical quality indicators, the milk mixture for the production of the synbiotic fermented milk product had high quality characteristics; its composition corresponded to the requirements for the dairy industry.

Oatmeal is a natural dietary product obtained from oats by flattening. The nutritional value of oatmeal is presented in Table 4.
As a result of the organoleptic assessment of quality of oat flakes by organoleptic indicators, the following data were obtained (Table 5).

According to the organoleptic quality indicators, oat flakes had high quality characteristics and met the requirements.

The results of the organoleptic and scoring assessment are presented in Table 6 .

Table 4. Nutritional Information of Oatmeal

\begin{tabular}{|l|c|}
\hline \multicolumn{1}{|c|}{ Indicators } & Value \\
\hline Calories, kcal & 379 \\
\hline Fats, $\%$ & 6.52 \\
\hline Protein, \% & 13.15 \\
\hline Carbohydrates, \% & 67.70 \\
\hline Water, \% & 10.84 \\
\hline
\end{tabular}


Table 5. The results of assessment of quality of oatmeal by organoleptic indicators

\begin{tabular}{|l|l|}
\hline \multicolumn{1}{|c|}{ Indicator } & \multicolumn{1}{c|}{ Characteristics of oat bran } \\
\hline Color & White with cream and yellow shades \\
\hline Smell & Inherent to oatmeal without moldy, musty and other extraneous odors \\
\hline Taste & Peculiar to oatmeal without smack of bitterness and extraneous smacks \\
\hline Presence of mineral impurities & When chewing bran, no crunch is felt \\
\hline
\end{tabular}

Table 6. Results of a score and organoleptic assessment of the quality of a synbiotic sour-milk product according to the experimental options, score

\begin{tabular}{|l|c|c|c|c|}
\hline \multicolumn{1}{|c|}{ Options } & $\begin{array}{c}\text { Appearance, } \\
\text { Consistency }\end{array}$ & Taste & Smell & Color \\
\hline $\begin{array}{l}\text { Sour-milk synbiotic } \\
\text { product (control) }\end{array}$ & $\begin{array}{c}\text { Viscous, uniform, } \\
\text { moderately thick } \\
(5)\end{array}$ & $\begin{array}{c}\text { Pure, sour milk } \\
(5)\end{array}$ & $\begin{array}{c}\text { Pure, sour milk } \\
(5)\end{array}$ & $\begin{array}{c}\text { White } \\
(3)\end{array}$ \\
\hline $\begin{array}{l}\text { Sour-milk synbiotic } \\
\text { product with oat flakes } \\
\text { added at } \mathrm{t}=92^{\circ} \mathrm{C} \text { (pas- } \\
\text { teurization) }\end{array}$ & $\begin{array}{c}\text { Moderately thick, } \\
\text { with a slight separa- } \\
\text { tion of serum } \\
(4)\end{array}$ & $\begin{array}{c}\text { Pure, sour milk, } \\
\text { oatmeal flavored } \\
(5)\end{array}$ & $\begin{array}{c}\text { Pure, milky, with a } \\
\text { grain smell (5) }\end{array}$ & $\begin{array}{c}\text { Light brown flake } \\
\text { interspersed } \\
(3)\end{array}$ \\
\hline $\begin{array}{l}\text { Sour-milk synbiotic } \\
\text { product prepared with } \\
\text { oat flakes added at } \mathrm{t}=65 \\
{ }^{\circ} \mathrm{C} \text { (cooling the milk } \\
\text { mixture) }\end{array}$ & $\begin{array}{c}\text { Moderately thick, } \\
\text { with a slight separa- } \\
\text { tion of serum } \\
(4)\end{array}$ & $\begin{array}{c}\text { Pure, sour milk, } \\
\text { oatmeal flavored } \\
(5)\end{array}$ & $\begin{array}{c}\text { Pure, milky, with a } \\
\text { grain smell } \\
(5)\end{array}$ & $\begin{array}{c}\text { Light brown flake } \\
\text { interspersed } \\
(3)\end{array}$ \\
\hline $\begin{array}{l}\text { Sour milk synbiotic } \\
\text { product with oat flakes } \\
\text { added at } \mathrm{t}=42^{\circ} \mathrm{C} \text { (fer- } \\
\text { mentation) }\end{array}$ & $\begin{array}{c}\text { Viscous, thick, } \\
\text { uniform, dense } \\
(5)\end{array}$ & $\begin{array}{c}\text { Pure, sour milk, } \\
\text { oatmeal flavored } \\
(5)\end{array}$ & $\begin{array}{c}\text { Pure, milky, with a } \\
\text { grain smell } \\
(5)\end{array}$ & $\begin{array}{c}\text { Light brown flake } \\
\text { interspersed } \\
(3)\end{array}$ \\
\hline $\begin{array}{l}\text { Sour-milk synbiotic } \\
\text { product prepared with } \\
\text { flakes added at } \mathrm{t}=10^{\circ} \mathrm{C} \\
\text { (cooling of the finished } \\
\text { product) }\end{array}$ & $\begin{array}{c}\text { Viscous, uniform, } \\
\text { moderately thick }\end{array}$ & $\begin{array}{c}\text { Pure, sour milk, } \\
\text { oatmeal flavored }\end{array}$ & $\begin{array}{c}\text { Pure, milky, with a } \\
\text { grain smell } \\
(5)\end{array}$ & $\begin{array}{c}\text { Light brown flake } \\
\text { interspersed } \\
(3)\end{array}$ \\
\hline
\end{tabular}

The synbiotic sour-milk product (control) had a pure, sour-milk taste without extraneous odors, a homogeneous, moderately thick, glossy consistency.

The synbiotic sour-milk product had a pure, sourmilk oatmeal taste.

Estimating the consistency of a synbiotic sour-milk product with oat flakes at a temperature of $\mathrm{t}=92{ }^{\circ} \mathrm{C}$ and $65{ }^{\circ} \mathrm{C}$, the separation of serum in the finished product was observed.

The consistency and appearance of the sour-milk synbiotic product with oat flakes introduced at the stage of fermentation at a temperature of $42{ }^{\circ} \mathrm{C}$ had a viscous, thick, dense and uniform consistency. This product had high quality characteristics. The consistency and appearance of the sour-milk synbiotic product with oat flakes introduced at the cooling stage at a temperature of $10{ }^{\circ} \mathrm{C}$ had a viscous, dense, uniform, but not dense consistency. This product has high quality characteristics.

The sour-milk synbiotic product had a white color corresponding to a sour-milk product without fillers.

All the test variants had a light brown color, with the presence of oat flakes which meets the requirements of GOST 334911-2015 "Sour-milk products enriched with bifidobacteria and bifidum. Technical conditions."

The scoring was carried out to identify the best experimental variant. The assessment was carried out by teachers of the Faculty of Technology.
Based on the tasting results obtained by Samara State Agrarian University, a score was identified. The results of scoring the sour-milk synbiotic product are presented in Table 7.

Table 7 shows that according to the sum of the maximum points, two experimental variants of a sour-milk synbiotic product were scored - a control one prepared without oatmeal and a sour-milk synbiotic product with oatmeal added at $\mathrm{t}=42{ }^{\circ} \mathrm{C}$ (18 points), a sour-milk synbiotic product with oatmeal added at $\mathrm{t}=10{ }^{\circ} \mathrm{C}(16.58$ points) and a sour-milk synbiotic product with oatmeal added at $\mathrm{t}=92{ }^{\circ} \mathrm{C}$ (17.42 points), a sour-milk synbiotic product with oatmeal added at $\mathrm{t}=65^{\circ} \mathrm{C}(17.42$ points $)$.

Physico-chemical and microbiological quality indicators of the symbiotic product (yogurt) are presented in Table 8 .

Table 8 shows that the fermented milk product with oatmeal which was introduced at high temperatures had low acidity. At the end of the shelf life, the maximum acidity was observed in variants with oat flakes added at a temperature of $42^{\circ} \mathrm{C}$ in conjunction with a starter culture. All options can be produced but adjusted quality of raw milk.

The change in titratable acidity in a synbiotic sourmilk product with oatmeal produced at different stages of production and at different temperatures is shown in Figure 2. 
Table 7. The results of the scoring of dairy synbiotic product

\begin{tabular}{|l|c|c|c|c|c|}
\hline \multicolumn{1}{|c|}{ Options } & \multicolumn{4}{c|}{ Indicators } \\
\cline { 2 - 6 } & appearance & consistency & $\begin{array}{c}\text { taste and } \\
\text { smell }\end{array}$ & color & Total \\
\hline $\begin{array}{l}\text { Sour-milk synbiotic product without flakes } \\
\text { (control) }\end{array}$ & $\begin{array}{c}5.0 \pm 0.00 \\
\text { (fine) }\end{array}$ & $\begin{array}{c}5.0 \pm 0.00 \\
\text { (fine) }\end{array}$ & $\begin{array}{c}5.0 \pm 0.00 \\
\text { (fine) }\end{array}$ & $\begin{array}{c}3.0 \pm 0 \\
\text { (fine) }\end{array}$ & $\begin{array}{c}18.00 \\
\text { (fine) }\end{array}$ \\
\hline $\begin{array}{l}\text { Sour-milk synbiotic product with oat flakes } \\
\text { at } \mathrm{t}=92^{\circ} \mathrm{C} \text { (pasteurization stage) }\end{array}$ & $\begin{array}{c}5.00 \pm 0.00 \\
\text { (fine) }\end{array}$ & $\begin{array}{c}4.71 \pm 0.49 \\
\text { (good) }\end{array}$ & $\begin{array}{c}4.71 \pm 0.49 \\
\text { (good) }\end{array}$ & $\begin{array}{c}3.0 \pm 0 \\
\text { (fine) }\end{array}$ & $\begin{array}{c}17.42 \\
\text { (good) }\end{array}$ \\
\hline $\begin{array}{l}\text { Sour-milk synbiotic product with oat flakes } \\
\text { added at t }=65^{\circ} \mathrm{C} \text { (cooling the milk mix- } \\
\text { ture) }\end{array}$ & $\begin{array}{c}5.00 \pm 0.00 \\
\text { (fine) }\end{array}$ & $\begin{array}{c}4.71 \pm 0.49 \\
\text { (good) }\end{array}$ & $\begin{array}{c}4.71 \pm 0.49 \\
\text { (good) }\end{array}$ & $\begin{array}{c}3.0 \pm 0 \\
\text { (fine) }\end{array}$ & $\begin{array}{c}17.42 \\
\text { (good) }\end{array}$ \\
\hline $\begin{array}{l}\text { Sour milk synbiotic product with oat flakes } \\
\text { added at } \mathrm{t}=42^{\circ} \mathrm{C} \text { (fermentation) }\end{array}$ & $\begin{array}{c}5.0 \pm 0.00 \\
\text { (fine) }\end{array}$ & $\begin{array}{c}5.0 \pm 0.00 \\
\text { (fine) }\end{array}$ & $\begin{array}{c}5.0 \pm 0.00 \\
\text { (fine) }\end{array}$ & $\begin{array}{c}3.0 \pm 0 \\
\text { (fine) }\end{array}$ & $\begin{array}{c}18.00 \\
\text { (fine) }\end{array}$ \\
\hline $\begin{array}{l}\text { Sour-milk synbiotic product with oat flakes } \\
\text { added at t }=10^{\circ} \mathrm{C} \text { (cooling of the finished } \\
\text { product) }\end{array}$ & $\begin{array}{c}5.0 \pm 0.00 \\
\text { (fine) }\end{array}$ & $\begin{array}{c}4.29 \pm 0.53 \\
\text { (good) }\end{array}$ & $\begin{array}{c}4.29 \pm 0.53 \\
\text { (good) }\end{array}$ & $\begin{array}{c}3.0 \pm 0 \\
\text { (fine) }\end{array}$ & $\begin{array}{c}16.58 \\
\text { (good) }\end{array}$ \\
\hline
\end{tabular}

Table 8. Physical and chemical and microbiological quality indicators of a fermented milk synbiotic product

\begin{tabular}{|l|c|c|c|c|c|}
\hline \multicolumn{1}{|c|}{ Options } & $\begin{array}{c}\text { Titratable acidi- } \\
\text { ty at the time of } \\
\text { production, }{ }^{\mathbf{0}} \mathbf{T}\end{array}$ & $\begin{array}{c}\text { End-of-life } \\
\text { titratable } \\
\text { acidity } \\
\mathbf{0} \mathbf{T}\end{array}$ & $\begin{array}{c}\text { Protein } \\
\text { content, } \\
\mathbf{\%}\end{array}$ & $\begin{array}{c}\text { The number } \\
\text { of microor- } \\
\text { ganisms, } \\
\text { CFU/g }\end{array}$ & $\begin{array}{c}\text { Yeast and } \\
\text { mold } \\
\text { CFU/g, }\end{array}$ \\
\hline Normative indicators & $\begin{array}{c}\text { no more than } \\
140\end{array}$ & $\begin{array}{c}\text { no more than } \\
140\end{array}$ & $\begin{array}{c}\text { no less than } \\
3.2\end{array}$ & $\begin{array}{c}\text { no less than } \\
1 \times 10^{7}\end{array}$ & $\begin{array}{c}\text { no more than } \\
50\end{array}$ \\
\hline $\begin{array}{l}\text { Sour-milk synbiotic product } \\
\text { (control) }\end{array}$ & 86 & 93 & 3.3 & $2.1 \times 10^{7}$ & No growth \\
\hline $\begin{array}{l}\text { Sour-milk synbiotic product } \\
\text { with oat flakes added at } \mathrm{t}=92 \\
{ }^{\circ} \mathrm{C} \text { (pasteurization) }\end{array}$ & 104 & 120 & 3.52 & $3.5 \times 10^{7}$ & No growth \\
\hline $\begin{array}{l}\text { Sour-milk synbiotic product } \\
\text { with the oat flakes added at } \mathrm{t}= \\
65^{\circ} \mathrm{C} \text { (cooling) }\end{array}$ & 104 & 125 & 3.51 & $3.7 \times 10^{7}$ & No growth \\
\hline $\begin{array}{l}\text { Sour milk synbiotic product } \\
\text { with oat flakes at } \mathrm{t}=42^{\circ} \mathrm{C} \\
\text { fermentation) }\end{array}$ & 110 & 128 & 3.52 & $1.1 \times 10^{8}$ & No growth \\
\hline $\begin{array}{l}\text { Sour-milk synbiotic product } \\
\text { with flakes added at } \mathrm{t}=10^{\circ} \mathrm{C} \\
\text { (cooling of the finished prod- } \\
\text { uct) }\end{array}$ & 86 & 100 & 3.53 & $2.5 \times 10^{7}$ & No growth \\
\hline
\end{tabular}

When assessing the fermented milk synbiotic product with oat flakes at various temperatures according to the microbiological parameters, the culture media were sown to determine the number of moldy fungi and the number of lactic microorganisms. The best development of lactic acid microorganisms occurred on media in the experimental variants: a dairy product with oat flakes, introduced with sourdough at a temperature of $42{ }^{\circ} \mathrm{C}(1.1$ $\times 108)$.

These microorganisms are high acid-forming and develop favorably in the acidic environment. The smallest development of lactic acid microorganisms occurs in the control variant of the experiment and in the variant with oat flakes at a temperature of $92^{\circ} \mathrm{C}$. In all cases, the content of lactic acid microorganisms is higher than normal.

Their survival during storage was determined on the 7 th day of the shelf life. The cell viability and their most probable number (LPC) were estimated by the method of limiting dilutions. The method is based on the seeding of a certain amount of the product or its dilutions in sterile skim milk.

The development of lactic acid microorganisms as a result of a change in titratable acidity in a synbiotic sourmilk product with oatmeal introduced at different stages of production and at different temperatures is shown in Figure 3. 


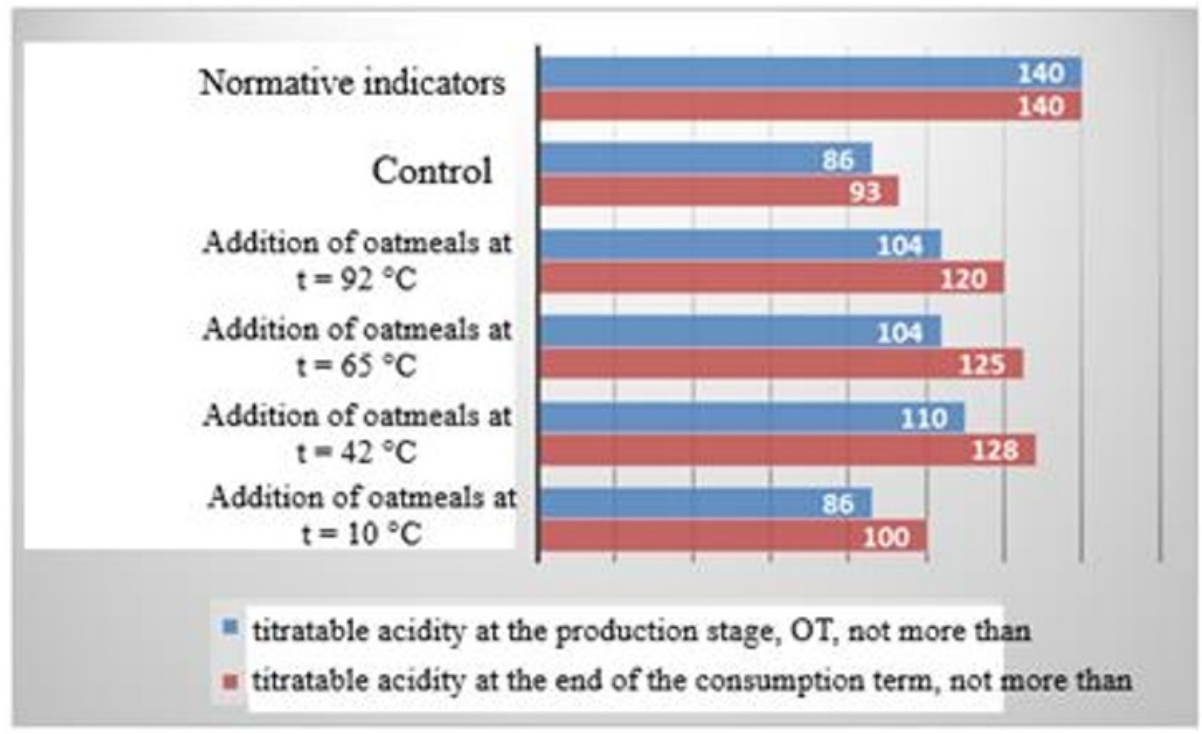

Fig. 2. Changes in titratable acidity during storage of a synbiotic sour-milk product with oatmeal produced at different stages of production and at different temperatures.

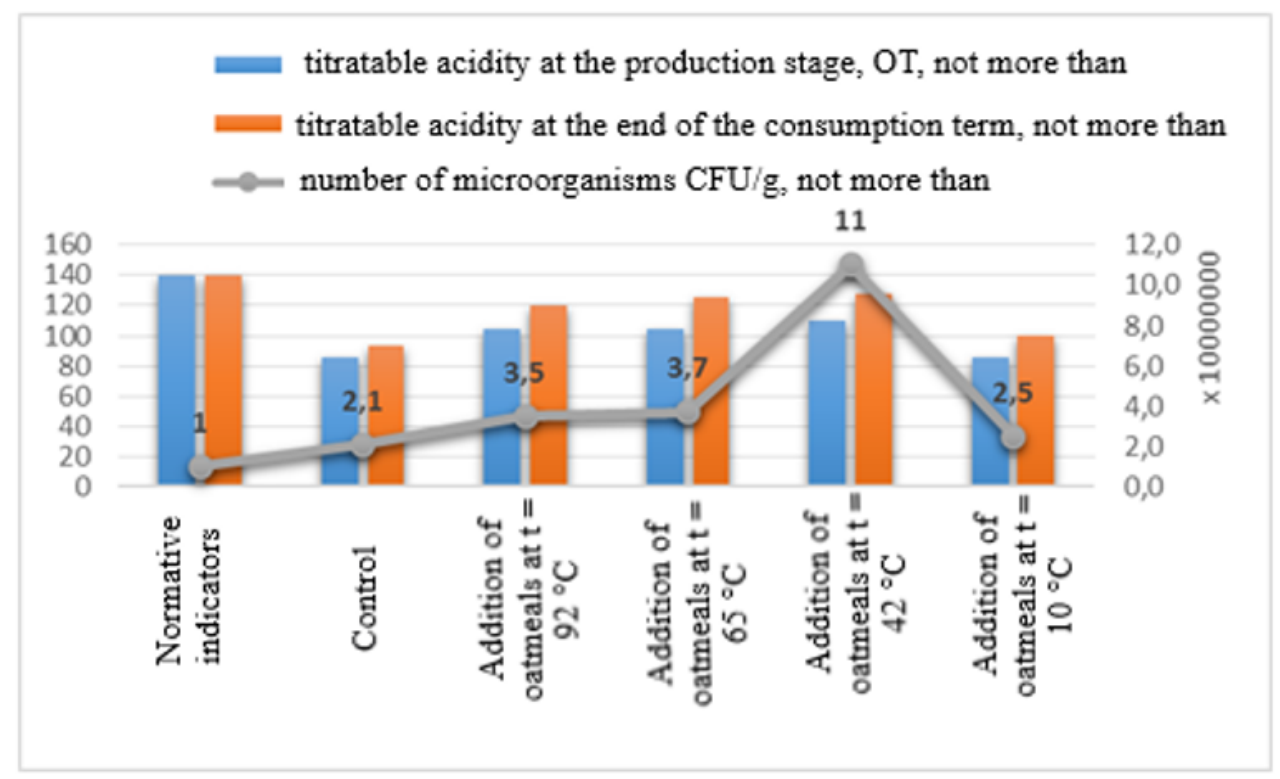

Fig. 3. The development of lactic acid microorganisms as a result of changes in titratable acidity in a synbiotic fermented milk product with oatmeal added at different stages of production and at different temperatures.

During the production of the fermented milk product, the fermentation time was determined, since this indicator affects the organoleptic properties of the product and the microbiological composition of the finished product. The ripening time is indicated in Table 9.

According to the results of this experiment, the following conclusion can be made: the introduction of oat- meal had an effect on the duration of fermentation (the development time of beneficial microflora). The control variant and the experimental one produced with the introduction of oat flakes at a temperature of $100^{\circ} \mathrm{C}$ were the slowest to ferment. When adding flakes, the ripening time was reduced by 2 hours in comparison with the control variant.

Table 9. Fermentation time

\begin{tabular}{|l|c|}
\hline \multicolumn{1}{|c|}{ Research option } & $\begin{array}{c}\text { Fermentation } \\
\text { time, h }\end{array}$ \\
\hline Sour-milk synbiotic product (control) & 6 \\
\hline Sour-milk synbiotic product with oat flakes added at $\mathrm{t}=92^{\circ} \mathrm{C}$ (pasteurization) & 5 \\
\hline Sour-milk synbiotic product with oat flakes added at $\mathrm{t}=65^{\circ} \mathrm{C}$ (cooling) & 5 \\
\hline Sour milk synbiotic product with oat flakes added at $\mathrm{t}=42^{\circ} \mathrm{C}$ (fermentation) & 4 \\
\hline Sour-milk synbiotic product with oat flakes added at $\mathrm{t}=10^{\circ} \mathrm{C}$ (cooling of the finished product) & 6 \\
\hline
\end{tabular}




\section{Discussion}

There are very few functional foods on the food market. Enterprises need to develop a product line with various probiotic and prebiotic additives.

The composition of oatmeal includes fiber which is useful for the digestive system and cleanses the body. Vitamins of group B are responsible for the condition of skin, nails, hair, making them more elastic and strong. Iodine affects the thyroid gland, strengthens the nervous system, improves the brain function. The composition also includes vitamins $\mathrm{A}$ and $\mathrm{E}$, which allow you to maintain beauty and youth.

According to the organoleptic characteristics, the synbiotic sour-milk product (control) has a clean, sourmilk taste, without extraneous odors, a homogeneous, moderately thick, glossy consistency.

The synbiotic sour-milk product prepared with the introduction of oatmeal (all test variants) had a pure, sourmilk and oatmeal taste. The synbiotic sour-milk product with oat flakes added at $\mathrm{t}=92{ }^{\circ} \mathrm{C}$ and $65^{\circ} \mathrm{C}$ had separated serum in the finished product.

All the experimental variants had a light brown color, with the presence of oat flakes, which meets the requirements of GOST 31981-2013 "Yoghurts. General specifications. "

Two options scored the maximum points: a sour-milk synbiotic product (control), a sour-milk synbiotic product with oatmeal at $\mathrm{t}=42{ }^{\circ} \mathrm{C}$ (18 points) received an "excellent" assessment, the sour-milk synbiotic product prepared with oatmeal at $\mathrm{t}=10{ }^{\circ} \mathrm{C}$ (16.58 points) received a "good" assessment, the fermented milk synbiotic product prepared with oatmeal added at $\mathrm{t}=92{ }^{\circ} \mathrm{C}$ (17.42 points) and the fermented milk synbiotic product with oatmeal added at $\mathrm{t}=65{ }^{\circ} \mathrm{C}$ ( 17.42 points) received a "good" assessment.

The dairy product with oatmeal added at high temperatures had a low acidity. At the end of the shelf life, the maximum acidity was observed in the options with oat flakes added at $\mathrm{t}=42{ }^{\circ} \mathrm{C}$ together with the starter culture.

The best development of lactic acid microorganisms occurred in the variant "the fermented milk product with oatmeal added at $\mathrm{t}=42{ }^{\circ} \mathrm{C}(1.1 \times 108)$ ". The smallest development of lactic acid microorganisms occurs in the control variant and in the variant with oat flakes added at $\mathrm{t}=10^{\circ} \mathrm{C}$. In all cases, the content of lactic acid microorganisms is higher than normal.

\section{Conclusion}

In recent years, there has been a trend to develop and produce special products. Improving food technology through the use of hydrated oatmeal makes it possible to enrich fermented milk products with proteins, dietary fiber, trace elements and vitamins. Oat flakes were used as a nutrient medium for microorganisms in a fermented milk product. Lactobacilli and acidophilus bacillus produce organic acids which leads to the inhibition of the vital activity of pathogenic microorganisms. The use of hydrated oat flakes in an amount of $6 \%$ at the stage of fermentization at a temperature of $420{ }^{\circ} \mathrm{C}$ has a positive effect on quality of the fermented milk product (yogurt) and development of lactic acid bacteria.

To increase the nutritional and biological value, oat hydrated flakes introduced together with the starter culture at a temperature of $42 \mathrm{C}$ in the amount of $6 \%$ can be used. These recommendations will help produce a product with the best consumer properties.

\section{References}

1. G.A. Donskaya, Functional dairy products Dairy industry 3, 52-53 (2007)

2. Z.S. Zobkova, T.P. Fursova, The effect of food additives and functional ingredients on the quality of whole milk products Dairy industry 2, 50-52 (2017)

3. I.V. Sukhova, D. Sh. Baimisheva, The influence of probiotic cultures on the quality of synbiotic sourmilk drinks in Collection of scientific papers of the int. scientific-practical conf. dedicated to the 20th anniversary of the technological faculty "Technology of storage and processing of agricultural products: quality and safety of raw materials and food products" 128-131 (Samara, 2014)

4. V.A. Smirnov, Traditional and non-traditional fillers Dairy industry 2, 56-57 (2018)

5. X. Lu, M. A. Brennan, L. Serventi, J. Liu, C. S. Brennan, Addition of mushroom powder to pasta enhances the antioxidant content and modulates the predictive glycaemic response of pasta Food Chemistry 264, 199-209 (2018)

6. E. Mohammadi-Gouraji, S. Soleimanian-Zad, M. Ghiaci, Phycocyanin-enriched yogurt and its antibacterial and physicochemical properties during 21 days of storage Int. J. of Biological Macromolecules 102, 230-236 (2019)

7. K. Das, R. Choudhary, K. A. Thompson-Witrick, Effects of new technology on the current manufacturing process of yogur Int. J. of Biological Macromolecules 108, 69-80 (2019) 